\title{
Caryophyllene-Type Sesquiterpenoids from the Stembark of Aglalia harmsiana and Their Cytotoxic Activity Against MCF-7 Breast Cancer Cells
}

\author{
Hersa Milawati', Desi Harneti', Rani Maharani ${ }^{1,2}$, Nurlelasari', Ace Tatang Hidayat ${ }^{1,2}$, \\ Mohamad Nurul Azmi ${ }^{3}$, Yoshihito Shiono ${ }^{4}$, Unang Supratman ${ }^{1,2^{*}}$
'Department of Chemistry, Faculty of Mathematics and Natural Sciences, Universitas Padjadjaran, Jatinangor 45363, Indonesia
${ }^{2}$ Central Laboratory of Universitas Padjadjaran, Jatinangor 45363, Indonesia
${ }^{3}$ School of Chemical Sciences, Universiti Sains Malaysia, 11800 Minden, Penang, Malaysia \\ ${ }^{4}$ Department of Food, Life, and Environmental Science, Faculty of Agriculture, Yamagata University, \\ Tsuruoka, Yamagata 997-8555, Japan.
}

*Corresponding author email: unang.supratman@unpad.ac.id

Received July 9, 2019; Accepted September 1, 2019; Available online November 30, 2019

\begin{abstract}
Sesquiterpenoid is a class of terpenoid compounds that have the most abundant diversity of structures and biological activities that can be found in natural resources. Tropical plants are main source of sesquiterpenoid compounds such as Aglaia genus belong to Meliaceae family. A. harmsiana is a species from Aglaia that only has few previous researchs. Therefore, the purpose of this study was to isolate and determine the structure of sesquiterpenoid compounds from stem bark $A$. harmsiana along with their cytotoxic activity against MCF-7 breast cancer cells. The isolation process begins by extracting powder from $A$. harmsiana stembark using $n$-hexane, ethyl acetate and methanol. All extracts were evaluated for their cytotoxic activity against MCF-7 breast cancer cells, and $n$-hexane extracts showed significant cytotoxic activity with $\mathrm{IC}_{50}$ values of $117.86 \mathrm{\mu g} / \mathrm{mL}$. Therefore, $n$-hexane extracts were further separated and purified by various chromatographic techniques to obtain compounds 1 and $\mathbf{2}$. Compounds 1 and $\mathbf{2}$ were elucidated their chemical structures by spectroscopic methods including IR, NMR, and MS as well as by comparison of data with literatures and identified as caryophyllene-type sesquiterpenoids, $\beta$-caryophyllene oxide (1) and senecrassidiol (2). Compounds 1 and 2 were submitted for cytotoxic eveluation on MCF-7 breast cancer cells and as a result, $\beta$ caryophyllene oxide (1) showed the stronger activity compared to senecrassidiol (2). These finding indicated that the cytotoxic activity of caryophyllene-type sesquiterpenoid are influenced by the presence of double bonds and configuration of methyl groups.
\end{abstract}

Key words: Aglaia harmsiana, $\beta$-caryophyllene oxide, senecrassidiol, sesquiterpenoid, cytotoxic activity

\section{INTRODUCTION}

The genus Aglaia is the largest genus of the family Meliaceae (Farabi et al., 2017). Aglaia comprises more than 100 species distributed mainly in India, Indonesia, Malaysia, and part of the Western Pacific region (Hidayat et al., 2018). In Indonesia, the flowers of $A$. odorata tradionally used as an insects repellent (Joycharat et al., 2010). Some of Aglaia species have been phytochemically observed previously. Its chemical constituent include diterpenoids (Yodsave et al 2012), rocaglamides (Pan, Woodard, Lucas, Fuch, \& Kinghorn, 2014), lignans (Sianturi et al., 2016), triterpenoids (Zhang,
Wang, Gu, \& Kong, 2010; Harneti et al., 2012; Awang et al., 2012), and sesquiterpenoids (Liv ef al., 2014). In total, less than twenty sesquiterpenoids were isolated previously from genus Aglaia species because this compound did not attract considerable attention.

Sesquiterpenoid can be classified based on the number of cyclics formed due to the modification of the cyclization reaction and rearrangement of the carbon skeleton. Based on the cyclic number, sesquiterpenoids are divided into four groups, namely sesquiterpenoid acyclic, monocyclic, bicyclic and tricyclic (Ludwiczuk, Skalcka-Wozniak \& 
Georgiev, 2017). Each sesquiterpenoid cyclic structure can consist of cyclopropane, cyclobutane, cyclopentane, cyclohexane to cycloheptane (Chappell and Coates, 2010). Therefore, more than 10000 types of sesquiterpenoids have been successfully isolated to date (Celik, Togar, Turkez \& Taspinar, 2014). The more abundant variety of cyclic sesquiterpenoid skeletons compared to other terpenoids is due to the presence of farnesil pyrophosphate (FPP) as precursors that have three double bonds with more flexible carbon chains (Chappell and Coates, 2010).

Besides its structural diversity, sesquiterpenoids are known for their abundant application and biological activity. Sesquiterpenoid has a stronger aroma than other terpenoids (Buckle, 2015). Sesquiterpenoids are widely used as raw materials in fragrances such as patchoulol compounds. Sesquiterpenoid has also been shown to be pharmacological activities such as antimalarial, cytotoxic, antifungal, antibacterial, antiviral, antiinflammatory, anti-inflammatory, and antinociceptive. Even some sesquiterpenoids have been used as medicine, one of which is artemisinin. Artemisinin is a sesquiterpenoid lactone isolated from Artemisia annua and has been used universally as a malaria drug (Awouafack, Tane, Kuete \& Eloff., 2013).

Aglaia species which have been shown to contain sesquiterpenoid compounds are $A$. minahassae (Kurniasih et al., 2018), A. foveolata (Roux et al., 1998), A. odorata (Liu and Xu, 2016), A. silvestris (Poitinger et al., 2008), A. grandis (Inada et al., 2000), A. perviridis (Pan et al., 2013) and A. leucophylla (Benosman, Richomme, Sevenet, Hadi \& Bruneton, 1994) with six sesquiterpenoid groups, namely sesquiterpenoid eudesmane, guaiane, aromadendrane, cadinene, isodaucane, and caryophyllene. Caryophyllene-type sesquiterpenoids, particularly caryophyllene oxide, has showed cytotoxic activity against various cancer cell lines, such as HepG2, AGS, HeLa, SNU-1, and SNU-16 (Jun et al., 2011)

Although sesquiterpenoids of other Aglaia species have been investigated previously, the sesquiterpenoid compounds of the stem bark of $A$. harmsiana is yet to be reported. The chemical constituents that have been reported previously from the leaves of $A$. harmsiana are cycloartane triterpenoids (Inada et al., 1997) and rocaglaol (Nugroho et al., 1997). In this paper, the isolation and structure identification of caryophyllene-type sesquiterpenoid along with their cytotoxic activity are described.

\section{EXPERIMENTAL SECTION}

\section{General Experiment Procedure}

The IR spectra were recorded on a SHIMADZU IR Prestige-21 in $\mathrm{KBr}$. The mass spectra were obtained with a Waters Xevo QTOF MS. NMR spectral data were recorded on JEOL ECZ-600 spectrometer at $600 \mathrm{MHz}$ for ${ }^{1} \mathrm{H}$ and $150 \mathrm{MHz}$ for ${ }^{13} \mathrm{C}$. Chemical shifts are given on a $\delta(\mathrm{ppm})$ scale with tetramethyl silane (TMS) as an internal standard. Column chromatography was conducted on silica gel 60 (70-230 and 230-400 mesh, Merck). TLC analysis was carried out on silica gel $60 \mathrm{GF}_{254}$ (Merck, $0.25 \mathrm{~mm}$ ) using various solvent systems, and spots were detected by irradiating under ultraviolet-visible light ( 257 and $364 \mathrm{~nm}$ ) and heating the silica gel plates sprayed with 10\% vanillin sulfat in ethanol.

\section{Plant Material}

The stembark of $A$. harmsiana were collected in Bogor Botanical Garden, Bogor, West Java Province, Indonesia in January 2016. The plant was identified by Mr. Ismail, the staff of Bogoriense Herbarium, Research Center for Biology, Indonesian Institute of Science, Bogor, Indonesia and a voucher specimen has been deposited at the herbarium.

\section{Extraction and Isolation}

The dried ground stembark $(1.70 \mathrm{~kg})$ of $A$. harmsiana was successively extracted with $n$-hexane $(10 \mathrm{~L})$, ethyl acetate $(10 \mathrm{~L})$ and methanol $(14 \mathrm{~L})$ at room temperature. Evaporation of the extracts in reduced pressure resulted the crude extracts of $n$ hexane (43.97 g), EłOAc (43.25 g), and methanol $(170.3 \mathrm{~g})$, respectively. All of the extract were evaluated for their cytotoxic activity against MCF-7 breast cancer lines and the $n$-hexane and ethyl acetate extracts showed significant cytotoxic activity with $\mathrm{IC}_{50}$ values of 117.8 and $235.5 \mu \mathrm{g} / \mathrm{mL}$, respectively.

The $n$-hexane soluble fraction $(40.0 \mathrm{~g})$ was separated by vacuum liquid chromatography (VLC) on silica gel $\mathrm{G} 60$ with $n$-hexane-ethyl acetatemethanol (100:0 - 0:100) as a solvent with a gradient of $10 \%$ to produced four combined subfractions (A-D). Subfraction B $(911.4 \mathrm{mg})$ was further separated by vacuum liquid chromatography eluted with $n$-hexane - dichloromethane (100:0$0: 100)$ in a gradient of $10 \%$, resulting in nine combined subfractions (B1-B9). Subfraction B6 $(664.8 \mathrm{mg})$ was separated by column 
chromatography on silica G60 (70-230 Mesh) eluted with $n$-hexane:dichloromethane:ethyl acetate (9:0.8:0.2) to produced twelve combined subfractions (B6A-B6L). Subfraction B6C (158.8 mg) was separated by column chromatography on silica RP-18 eluted with methanol: acetonitrile:water (6:2:2) to produce two combined subfractions (B6C1 and $\mathrm{B} 6 \mathrm{C} 2$ ). Finally, subtractions $\mathrm{B} 6 \mathrm{C} 1$ (32.2 $\mathrm{mg}$ ) was separated using column chromatography on silica G60 (230-400 Mesh) eluted with n-hexan: dichloromethane:ethyl acetate $(1: 1.4: 0.6)$ to give compound $1(7.9 \mathrm{mg})$. While, subtraction B6C2 $(58.3 \mathrm{mg})$ was separated using column chromatography on silica G60 (230-400 Mesh) eluted with $n$-hexane : dichloromethane $(7: 3)$ to give compound 2 (26.0 mg).

\section{$\beta$-Caryophyllene Oxide ( 1 )}

Colourless oil; IR (KBr) $v_{\max } 3069,2930,1633$, 1368, 1384 and $1075 \mathrm{~cm}^{-1}$; ${ }^{1} \mathrm{H}-\mathrm{NMR}\left(\mathrm{CDCl}_{3}, 600\right.$ $\mathrm{MHz})$ and ${ }^{13} \mathrm{C}-\mathrm{NMR}\left(\mathrm{CDCl}_{3}, 150 \mathrm{MHz}\right)$ see Table 1; HR-TOFMS m/z 221.2001 [M+H] ${ }^{+}$, (calcd. $\mathrm{C}_{15} \mathrm{H}_{25} \mathrm{O}$ $\mathrm{m} / \mathrm{z} 221.1905$ ).

\section{Senecrassidiol (2)}

Colourless oil; IR (KBr) $v_{\max } 3421,2949,2861$, $1620,1462,1361,1384,1359$ and $1078 \mathrm{~cm}^{-1} ;{ }^{1} \mathrm{H}-$ NMR $\left(\mathrm{CDCl}_{3}, 600 \mathrm{MHz}\right)$ and ${ }^{13} \mathrm{C}-\mathrm{NMR}\left(\mathrm{CDCl}_{3}, 150\right.$ $\mathrm{MHz}$ ) see Table 1; HR-TOFMS $\mathrm{m} / \mathrm{z} 220.1825$ $[\mathrm{M}+\mathrm{H}]^{+}$, (calcd. $\mathrm{C}_{15} \mathrm{H}_{24} \mathrm{O} \mathrm{m} / \mathrm{z} 221.1827$ ).

\section{Bioassays for Cytotoxic Activity}

The MCF-7 cells were seeded into 96-well plates at an initial cell density of approximately $3 \times 10^{4}$ cells $\mathrm{cm}^{-3}$. After $24 \mathrm{~h}$ of incubation for cell attachment and growth, varying concentrations of samples were added. The compounds added were first dissolved in DMSO at the required concentration. Subsequent six desirable concentrations were prepared using PBS (phosphoric buffer solution, $\mathrm{pH}=7.30-7.65$ ). Control wells received only DMSO. The assay was terminated after a $48 \mathrm{~h}$ incubation period by adding MTT reagent [3-(4,5-dimethylthiazol-2-yl)-2,5diphenyl tetrazolium bromide; also named as thiazol blue] and the incubation was continued for another $4 \mathrm{~h}$, in which the MTT-stop solution containing SDS (sodium dodecyl sulphate) was added and another $24 \mathrm{~h}$ incubation was conducted. Optical density was read by using a micro plate reader at $550 \mathrm{~nm}$. IC 50 values were taken from the plotted graph of percentage live cells compared to control (\%), receiving only PBS and DMSO, versus the tested concentration of compounds $(\mu \mathrm{M})$. The $I C_{50}$ value is the concentration required for $50 \%$ growth inhibition. Each assay and analysis was run in triplicate and averaged.

\section{RESULTS AND DISCUSSION}

The $n$-hexane extract of the stembark of $A$. harmsiana was chromatographed over a vacuumliquid chromatographed (VLC) column packed with silica gel 60 by gradient elution. The VLC fractions were repeatedly subjected to silica gel and silica RP18 column chromatography afforded a compounds 1 and 2 (Figure 1 ).

Compound 1 was obtained as a colorless oil which dissolves in chloroform and gives an orange color after being sprayed with $10 \%$ sulfuric acid in ethanol, indicated the presence of terpenoid structure. Compound $\mathbf{1}$ has the characteristic of not glowing under UV light at wavelengths of $254 \mathrm{~nm}$ and $365 \mathrm{~nm}$, indicated there is no conjugated double bond in compound 1 . The molecular formula of compound 1 was identified as $\mathrm{C}_{15} \mathrm{H}_{24} \mathrm{O}$ based on the HR-TOFMS $\mathrm{m} / \mathrm{z}[\mathrm{M}+\mathrm{H}]^{-}$221.2001, with calculations for $\mathrm{C}_{15} \mathrm{H}_{25} \mathrm{O} \mathrm{m} / \mathrm{z} 221.1905$, thus obtaining four hydrogen deficiency index. The IR spectra showed absorption peaks due to of an isolated double bond $\left(1633 \mathrm{~cm}^{-1}\right)$, an aliphatic $\left(2930 \mathrm{~cm}^{-1}\right)$, gem-dimethyl (1368 and $\left.1384 \mathrm{~cm}^{-1}\right)$ and an ether group $\left(1074 \mathrm{~cm}^{-1}\right)$. Based on the ${ }^{1} \mathrm{H}$ NMR spectrum of compound 1, displayed the presence of three tertiary methyl signals at $\delta_{\mathrm{H}} 0.97$, 0.98 and 1.20 , respectively. Then, the presence of a typical signal for olefinic protons at $\delta_{H} 4.96$ and 4.83 with a J1,2 $1.8 \mathrm{~Hz}$, which is the pairing constant for the geminal proton of terminal double bond. In addition, the signal for the oxygenated proton at $\delta_{\mathrm{H}}$ 2.87 was also observed in the ' $\mathrm{H}-\mathrm{NMR}$ spectrum. Based on the ${ }^{13} \mathrm{C}-\mathrm{NMR}$ spectrum with detailed analysis of Distortionless Enhancement by Polarization Transfer (DEPT) and Heteronuclear Multiple-Quantum Correlation) experiment (HMQC) measurements showed the presence of fifteen carbon signals consisting of three methyl tertiary which resonance at $\delta_{c} 17.0$ (Me-12), 21.5 (Me-14) and 29.9 (Me-15), five methylene at $\delta_{c} 27.0$ (C-2), 39.0 (C-3), 30.2 (C-6), 29.7 (C-7) ) and 39.7 (C10), two methines at $\delta_{C} 50.9$ (C-1) and $48.9 \mathrm{ppm}$ (C-9), one oxygenated methine $\delta_{c} 64$ (C-5), one quaternary carbon at $\delta_{c} 34.0$ (C-11), one oxygenated quaternary carbon at $\delta_{c} 59.8$ (C-4), one $\mathrm{sp}^{2}$ quaternary carbon at $\delta_{c} 151.9$ (C-8) and one $\mathrm{sp}^{2}$ methylene carbon at $\delta c 113.0$ (C-13). These functionalities accounted for one out of the total four hydrogen deficiency index. Three remaining hydrogen deficiency index was corresponded to the 
tricyclic sesquiterpenoid structure and one cyclic comes from an epoxide group (Kurniasih et al., 2018; Roux et al., 1998; Liv et al., 2014).

In order to determine the position of functional group in compound 1, ( $1 \mathrm{H}-{ }^{1} \mathrm{H}$-Correlated Spectroscopy ('H-' ${ }^{1} \mathrm{H}$ COSY) and Heteronuclear Multiple-Bond Correlation spectroscopy (HMBC) spectra (Figure 2). Correlations in vicinal protons
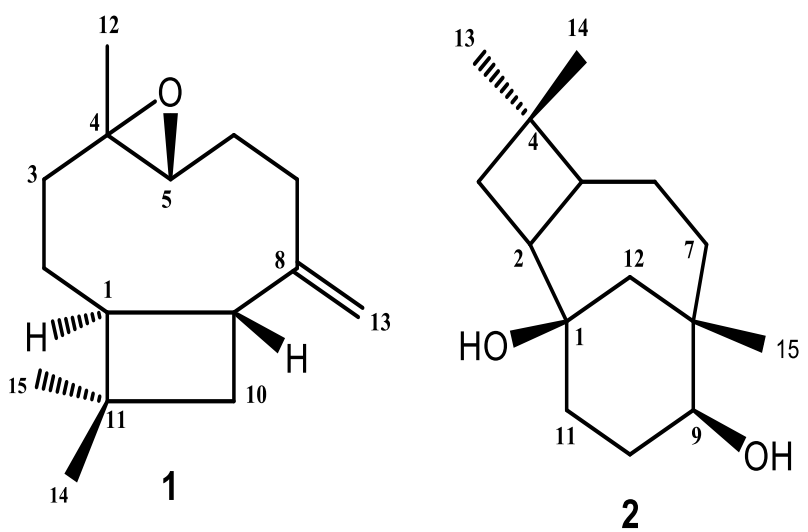

Figure 1. Chemical Structures of Compounds 1 and 2

were correlated to oxygenated carbon at $\delta_{c} 59.7$, suggested that the remaining methyl was attached at C-4 and an epoxy ring was located at C-4 and C-5. An olefinic protons at $\delta_{H} 4.83$ and 4.96 were mutually coupled and correlated to $\mathrm{sp}^{2}$ quaternary carbon at $\delta_{c} 151.9$, suggested that double bond terminal was located at C-8.

The relative stereochemistry of compound 1 was supported by nuclear Overhauser effect spectroscopy (NOESY) spectrum (Figure 3) and based on a biogenetic point of view the occurrence of caryophyllene-type sesquiterpenoid in Aglaia genus. Based on the biosynthesis of $\beta$ caryophyllene, the position of hydrogen in $\mathrm{C}-1$ has an $\alpha$-orientation, whereas hydrogen in C-9 has an $\beta$ orientation (Dewick, 2009). In the NOESY spectrum in $\mathrm{C}_{3}-\mathrm{C}_{2}-\mathrm{C}_{1}-\mathrm{C}_{9}-\mathrm{C}_{10}$ and $\mathrm{C}_{5}-\mathrm{C}_{6}-\mathrm{C}_{7}$, supporting the presence of caryophyllene-type sesquiterpenoid skeleton in compound 1 . Two methyl tertiary at $\delta_{\mathrm{H}}$ $0.98(\mathrm{Me}-14)$ and 0.97 (Me-15) were correlated to $\mathrm{sp}^{3}$ quaternary carbon at 34.1 (C-11), indicated that gem-dimethyl was attached at C-11. Another methyl tertiary at $\delta_{\mathrm{H}} 1.20$ and oxygenated methine at $\delta_{\mathrm{H}}$ 2.87
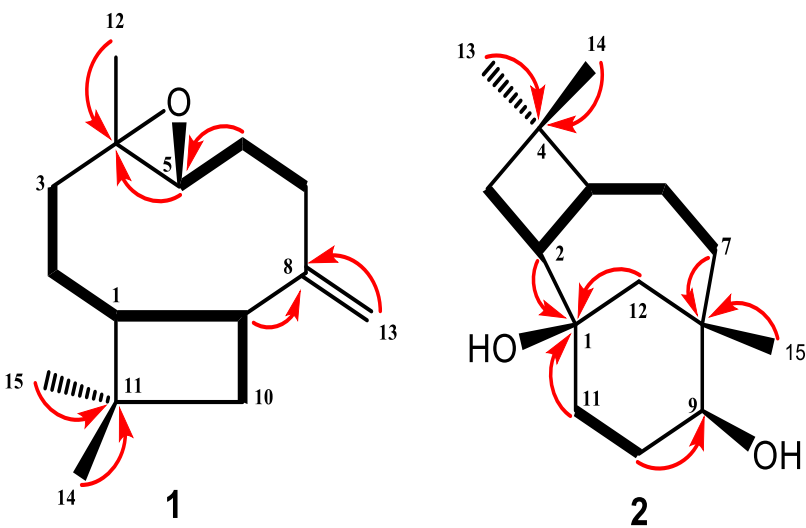

Figure 2. Selected ${ }^{1} \mathrm{H}-{ }^{1} \mathrm{H}$ COSY and $\mathrm{HMBC}$ Correlations for Compounds 1 and 2

of compound 1, there is no cross peak between $\mathrm{H}-1$ and $\mathrm{H}-9, \mathrm{H}-\mathrm{-}$ and $\mathrm{H}-9$, indicated those proton located in different sides. In the NOESY spectrum also showed correlation between $\mathrm{H}_{5}-\mathrm{H}_{1}$ and $\mathrm{H}_{14}$, indicated that the hydrogen in $\mathrm{C}-5$ and methyl at $\mathrm{C}$ 14 are $\alpha$-oriented, consequently, the oxygen in C-5 is $\beta$-oriented. A detailed comparison of compound $\mathbf{1}$ to those of $\beta$-caryophyllene oxide was isolated from Caesalpinia pulcherrima (Ragasa, Ganzon, Hofilena, Tamboong, \& Rideout, 2003), revealed that both compounds were very similar, consequently compound 1 was identified as a $\beta$ caryophyllene oxide. That compound was isolated also from Caesalpinia pulcherrima belong to Fabaceae family (Ragasa et al., 2003), but was isolated from Aglaia species for first time.

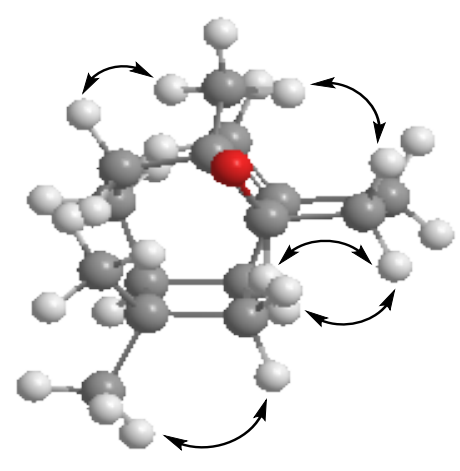

1

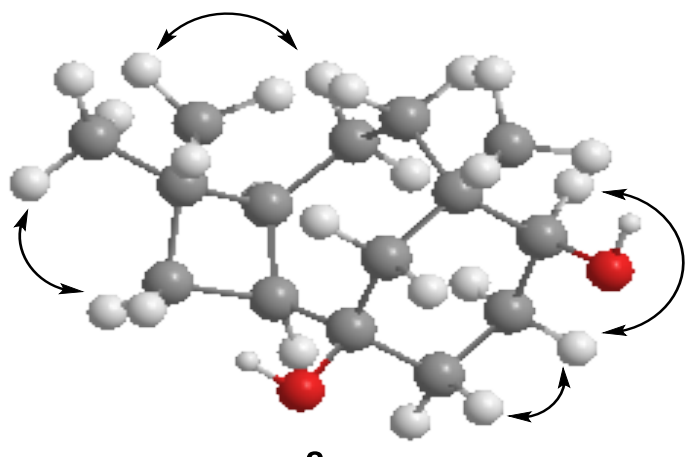

2

Figure 3. Selected NOE correlations for 1 and 2 
Table 1. NMR data for Compounds 1 and $2\left(\mathrm{CDCl}_{3}, 600 \mathrm{MHz}\right.$ for ${ }^{1} \mathrm{H}$ and 150 for $\left.{ }^{13} \mathrm{C}\right)$

\begin{tabular}{|c|c|c|c|c|}
\hline \multirow{2}{*}{$\begin{array}{l}\text { Position } \\
\text { Carbon }\end{array}$} & \multicolumn{2}{|l|}{1} & \multicolumn{2}{|l|}{2} \\
\hline & $\delta_{\mathrm{H}}[(\Sigma \mathrm{H}$, mult., $J(\mathrm{~Hz})]$ & $\delta_{c}$ (mult.) & $\delta_{\mathrm{H}}[(\Sigma \mathrm{H}$, mult., $J(\mathrm{~Hz})]$ & $\delta_{c}$ (mult.) \\
\hline 1 & $1.75(1 \mathrm{H}, \mathrm{t}, 10.2)$ & $50.7(d)$ & - & $69.7(\mathrm{~s})$ \\
\hline 2 & $\begin{array}{l}1.65(1 \mathrm{H}, \mathrm{m}) \\
1.60(1 \mathrm{H}, \mathrm{m})\end{array}$ & $27.3(t)$ & $2.13(1 \mathrm{H}, \mathrm{t}, 11.5)$ & 37.1 (d) \\
\hline 3 & $\begin{array}{l}2.05(1 \mathrm{H}, \mathrm{m}) \\
2.09(1 \mathrm{H}, \mathrm{m})\end{array}$ & $39.2(t)$ & $\begin{array}{l}1.08(1 \mathrm{H}, \mathrm{d}, 3.1) \\
1.06(1 \mathrm{H}, \mathrm{d}, 3.8)\end{array}$ & $33.0(t)$ \\
\hline 4 & - & $59.7(\mathrm{~s})$ & - & $34.0(\mathrm{~s})$ \\
\hline 5 & $2.87(1 \mathrm{H}, \mathrm{dd}, 4.2,9.8)$ & 63.9 (d) & $1.80(1 \mathrm{H}, \mathrm{m})$ & 42.9 (d) \\
\hline 6 & $\begin{array}{l}2.08(1 \mathrm{H}, \mathrm{m}) \\
2.12(1 \mathrm{H}, \mathrm{m})\end{array}$ & $29.8(t)$ & $\begin{array}{l}1.45(1 \mathrm{H}, \mathrm{m}) \\
1.32(1 \mathrm{H}, \mathrm{m})\end{array}$ & $19.4(t)$ \\
\hline 7 & $\begin{array}{l}2.21(1 \mathrm{H}, \mathrm{m}) \\
2.28(1 \mathrm{H}, \mathrm{m})\end{array}$ & $30.3(t)$ & $\begin{array}{l}1.39(1 \mathrm{H}, \mathrm{m}) \\
1.34(1 \mathrm{H}, \mathrm{m})\end{array}$ & $41.1(t)$ \\
\hline 8 & - & 151.9 (s) & - & $38.3(\mathrm{~s})$ \\
\hline 9 & $2.60(1 \mathrm{H}, \mathrm{q}, 10.2)$ & $48.8(d)$ & $3.36(1 \mathrm{H}, \mathrm{t}, 2.65)$ & 71.2 (d) \\
\hline 10 & $\begin{array}{l}1.68(1 \mathrm{H}, \mathrm{m}) \\
1.59(1 \mathrm{H}, \mathrm{m})\end{array}$ & $39.8(t)$ & $\begin{array}{l}1.96(1 \mathrm{H}, \mathrm{m}) \\
1.68(1 \mathrm{H}, \mathrm{m})\end{array}$ & $27.1(t)$ \\
\hline 11 & - & $34.1(\mathrm{~s})$ & $\begin{array}{l}1.57(1 \mathrm{H}, \mathrm{d}, 4.6) \\
1.43(1 \mathrm{H}, \mathrm{d}, 2.7)\end{array}$ & $32.4(t)$ \\
\hline 12 & $1.20(3 \mathrm{H}, \mathrm{s})$ & $17.1(q)$ & $\begin{array}{l}1.32(1 \mathrm{H}, \mathrm{d}, 13.0) \\
1.07(1 \mathrm{H}, \mathrm{d}, 13.0)\end{array}$ & $34.4(t)$ \\
\hline 13 & $\begin{array}{l}4.96(1 \mathrm{H}, \mathrm{d}, 1.8) \\
4.83(1 \mathrm{H}, \mathrm{d}, 1.8)\end{array}$ & $112.9(t)$ & $0.94(3 \mathrm{H}, \mathrm{s})$ & 19.8 (q) \\
\hline 14 & $0.98(3 \mathrm{H}, \mathrm{s})$ & $21.7(q)$ & $0.92(3 \mathrm{H}, \mathrm{s})$ & 29.5 (q) \\
\hline 15 & $0.97(3 \mathrm{H}, \mathrm{s})$ & 29.9 (q) & $0.85(3 \mathrm{H}, \mathrm{s})$ & $25.6(q)$ \\
\hline
\end{tabular}

Compound 2 is obtained as colourless oil. The molecular formula of 2 is determined as $\mathrm{C}_{15} \mathrm{H}_{26} \mathrm{O}_{2}$ based on HRTOFMS spectra and NMR spectral data (Table 1). With the negative ion mode, the molecular ion peak $\left[\mathrm{M}-\mathrm{H}_{2} \mathrm{O}\right]$ is obtained at $\mathrm{m} / \mathrm{z}$ 220.1825 , calculated as $\mathrm{m} / \mathrm{z} 220.1827$ as $\mathrm{C}_{15} \mathrm{H}_{24} \mathrm{O}$, thus obtaining three hydrogen deficiency index. The IR spectrum of $\mathbf{2}$, showed the presence the typical absorbance of a hydroxy group was observed at $v_{\max } 3421 \mathrm{~cm}^{-1}$, stretch of aliphatic at $v_{\max } 2980$ and $2870 \mathrm{~cm}^{-1}$ and stretch of C-O at $v_{\max }$ $1078 \mathrm{~cm}^{-1}$.

The 'H-NMR spectrum of $\mathbf{2}$ displayed the presence of three tertiary methyl signals at $\delta_{\mathrm{H}} 0.94$ $(3 \mathrm{H}, \mathrm{s}, \mathrm{Me}-12), 0.92(3 \mathrm{H}, \mathrm{s}, \mathrm{Me}-14)$ and $0.85(3 \mathrm{H}$, $\mathrm{s}$, Me-13), indicated the characteristics of caryophyllene-type sesquiterpenoid (Fraga et al., 2014). The presence of an oxygenated methine signal at $\delta_{H} 3.36(1 \mathrm{H}, \mathrm{d}, J=2.65 \mathrm{~Hz}, \mathrm{H}-9)$ and other aliphatic signals in the upfield region were also observed in the ${ }^{1} \mathrm{H}$ NMR spectrum. The ${ }^{13} \mathrm{C}-\mathrm{NMR}$ spectrum of $\mathbf{2}$ along with DEPT experiments indicated the presence of fifteen carbon signals consisting of three tertiary methyl at $\delta_{c}[29.5$ (Me13), 19.8 (Me-14) and 25.6 (Me-15)], six methylene signals at $\delta_{c}[33.0$ (C-3), 19.4 (C-6), 41.1 $(\mathrm{C}-7), 21.1(\mathrm{C}-10)$ and $32.3(\mathrm{C}-11)]$, three $\mathrm{sp}^{3}$ methine at $\delta_{C}[37.1(C-2)$ and 42.9 (C-5)], one oxygenated $\mathrm{sp}^{3}$ methine at $\delta_{c}[71.2$ (C-3)] and one oxygenated $\mathrm{sp}^{3}$ quaternary carbon at $\delta c[69.7$ (C$3)]$. There is no functionalities based on NMR spectra, consequently, three degrees of unsaturation were consistent with tricyclic caryophyllene-type sesquiterpenoid (Fraga et al., 2014). Furthermore, the chemical structure of $\mathbf{2}$ was deduced from the ${ }^{1} \mathrm{H}-{ }^{1} \mathrm{H}$ COSY and $\mathrm{HMBC}$ spectra (Figure 2). ${ }^{1} \mathrm{H}-{ }^{1} \mathrm{H}-$ COSY corelations at $\mathrm{C}_{5}-\mathrm{C}_{2}-\mathrm{C}_{3}-\mathrm{C}_{6}-\mathrm{C}_{7}$ and $\mathrm{C}_{9}-\mathrm{C}_{10}-\mathrm{C}_{11}$, supporting the presence of caryophyllene-type sesquiterpenoid in 2. Two methyl signals at $\delta_{\mathrm{H}} 0.92$ and 0.94 were correlated to $\mathrm{sp}^{3}$ quaternary carbon at $\delta_{c} 34.0$, suggested that gem-dimethyl were attached at $\mathrm{C}-4$. A methyl signal at $\delta_{\mathrm{H}} 0.85$ was correlated to $\mathrm{sp}^{3}$ quaternary carbon at $\delta_{c} 38.3$ and oxygenated carbon at $\delta_{c} 71.2$, indicated that another tertiary methyl located at C-8. An oxygenated methine at $\delta_{H} 3.36$ was correlated to quaternary carbon at $\delta_{c} 38.3$ (C-8) and methylene carbon at $\delta_{c} 27.1$ (C-10), suggested that a secondary hydroxy was located at C-9. A methine proton at $\delta_{H} 2.13$, methylene proton at $\delta_{H} 1.32$ and 
1.57 were correlated to oxygenated carbon at $\delta c$ 69.7 (C-1), indicated that a tertiary alcohol was located at C-1. A detailed comparison of NMR spectra of compound $\mathbf{2}$ to those of tricylic caryophyllene-type sesquiterpenoid, senecrassidiol (Fraga et al., 2014), revealed that both compounds were very similar, consequently compound $\mathbf{2}$ was identified as a senecrassidiol. The relative stereochemistry was determined as a senecrassidiol based on the similirity of coupling constant $\left({ }^{3} \mathrm{~J}\right)$ values in the ${ }^{1} \mathrm{H}$ NMR spectrum and others similarity. Consequently compound 1 was identified as a senecrassidiol. That compound was isolated also from Root Cultures and Aerial Parts of Bethencourtia hermosae (Fraga et al., 2014), but was isolated from $A$. harmsiana for first time.

Compounds 1 and 2 were evaluated for their cytotoxicity against MCF-7 breast cancer cell line according to a method previously described (Supratman et al., 2019; Supriatno et al., 2018), using cisplatin as positive control (Hadisaputri et al., 2012; Chavoshi et al., 2017) and the results showed that $\beta$-caryophyllene oxide (1) stronger cytotoxic activity than senecrassidiol (2) with $\mathrm{IC}_{50}$ values of 0.62 and $1.32 \mu \mathrm{M}$, respectively. These results indicated that the cytotoxic activity of caryophyllenetype sesquiterpenoid are affected by the presence of double bonds and configuration of methyl groups.

\section{CONCLUSIONS}

Two known caryophyllene-type sesquiterpenoid, $\beta$-caryophyllene oxide (1) and senecrassidiol (2) have been isolated from the stembark of $A$. hamrsiana. The discovery of two sesquiterpene compounds from the stembark of $A$. minahassaealso reinforces previous phytochemical studies of the occurance of sesquiterpenoid in the Aglaia genus. $\beta$ caryophyllene oxide (1) showed the stronger cytotoxic activity than senecrassidiol (2) against MCF-7 breast cancer lines, indicated that the cytotoxic activity of caryophyllene-type sesquiterpenoid are influenced by the presence of double bonds and configuration of methyl groups.

\section{ACKNOWLEDGMENTS}

This investigation was financially supported by Universitas Padjadjaran for financial support (Academic Leadership Grant 2018 by Unang Supratman). We are thank also to Ms. Mia Kusmiati at Central Laboratory, Universitas Padjadjaran, Bandung, Indonesia for MCF-7 evaluation.

\section{REFERENCES}

Awang, K., Loong, X.M., Leong, K.H., Supratman, U., Litaudon, M., Mukhtar, M.R., Mohamad, K. (2012). Triterpenes and steroids from the leaves of Aglaia exima (Meliaceae). Fitoterapia, 83, 1391-1395.

Awouafack, M. D., Tane, P., Kuete, V., \& Eloff, J. N. (2013). Sesquiterpenes from the medicinal plants of africa. medicinal plant research in africa, pharmacology and chemistry. Elsevier, 33-103.

Benosman, A., Richomme, P., Sevenet, T., A. Hadi, A.H., \& Bruneton, J. (1994). Secotirucallane triterpenes from the stem bark of Aglaia leucophylla. Phytochemistry, 37, 11431145.

Buckle, J. (2015). Basic plant taxonomy, basic essential oil chemistry, extraction, biosynthesis, and analysis. clinical aromatherapy, 37-72.

Celik, K., Togar, B., Turkez, H., and Taspinar, N. (2014). In vitro cytotoxic, genotoxic, and oxidative effect of acyclic sesquiterpene farnesene. Turkish Journal of Biology, 38, 253-259.

Chappell, J. and Coates, R.M. (2010). Sesquiterpenes. Comprehensive Natural Products II. 609-641.

Chavoshi, H., Vahedian, V., Saghaei, S., Pirouzpanah, M.B., Raeisi, M., Samadi, N. (2017). Adjuvant therapy with silibinin improves the efficacy of paclitaxel and cisplatin in mcf-7 breast cancer cells. Asian Pacific Journal of Cancer Prevention, 18(8), 2243-2247.

Dewick, P. M. (2009). Medicinal natural product a biosynthetic approach third edition. John Wiley and Sons. United Kingdom.

Farabi, K., Harneti, D., Nurlelasari, Maharani, R., Hidayat, A. C., Awang, K., Supratman, U., \& Shiono, Y. (2017). New cytotoxic protolimonoids from the stembark of Aglaia argentea (Meliaceae). Phytochemistry Letters, 21, $211-215$.

Fraga, B. M., Diaz, C. E., Amador, L. J., Reina, M., Santana, O., \& Gonzalez-Coloma, A.. (2014). Bioactive compounds from transfromed root cultures and aerial parts of Bethencourtia hermosae. Phytochemistry, 108, 220-228.

Hadisaputri, Y.E., Pharm, D., Miyazaki, T., Suzuki, S., Yokobori, T., Kobayashi, T., Tanaka, N., Inose, T., Sohda, M., Kuwano, H. (2012). 
TNFAIP8 overexpression: clinical relevance to esophageal squamous cell carcinoma. Annals of Surgical Oncology, 19, S589-S596.

Harneti, D., Tiokronegoro, R., Safari, A., Supratman, U., Loong, X.M., Mukhtar, M.R., Mohamad, K., Awang, K., Hayashi, H. (2012). Cytotoxic triterpenoids from the bark of Aglaia smithii. Phytochemistry Letter, 5, 496-499

Hidayat, A. C., Farabi, K., Harneti, D., Nurlelasari, Maharani, R., Nurfarida, I., Supratman, U., \& Shiono, Y. (2018). Cytotoxic Triterpenoids from the Stembark of Aglaia argentea (Meliaceae). Indonesia Journal of Chemistry, 18(1), 35-42

Inada, A., Shono, K., Murata, H., Inatomi, Y., Darnaedi, D., Nakanishi, T. (2000). Three putrescine bisamides from the leaves of Aglaia grandis. Phyłochemistry, 53, 10911095.

Inada, A., Ohtsuki, S., Sorano, T., Murata, H., Inatomi, Y., Darnaedi, D., \& Nakanishi, T.. (1997). cycloartane triterpenoids from Aglaia harmsiana. Phyłochemistry, 46, 379-381.

Jun, N. J., Mosaddik, A., Moon, J. Y., Jang, K. C., Lee, D. S., Ahn, K. S., \& Cho, S. K.. (2011). Cytotoxic activity of 6 -caryophyllene oxide isolated from jeju guava (Psidium cattleianum Sabine) leaf. Record of Natural Product, 5(3), 242-245

Joycharat, N., Thammavong, S., Voravuthikunchai, S.P., Plodpai, P., Mitsuwan, W., Limsuwan, S., and Subhadhirasakul, S., 2010, Chemical constituents and antimicrobial properties of the essential oil and ethanol extract from the stem of Aglaia odorata Lour, Natural Product Research, 28 (23), 2169-2172

Kurniasih, N., Milawati, H., Fajar, M., Hidayat, A.C., Abdullah, R., Harneti, D., Supratman, U., Azmi, N.M. (2018). Sesquiterpenoid compounds from the stembark of Aglaia minahassae (Meliaceae). Jurnal Molekul, 13 (1), $56-62$.

Liu, S., Liu, S. B., Zuo, W., Guo, Z., Mei, W., \& Dai, H. (2014). New Sesquiterpenoids from Aglaia odorata var. microphyllina and their cytotoxic activity. Fitoterapia. 92, 93-99.

Liv, B. and $X_{U}$, Y. K. (2016). Cytotoxicity and Synergistic Effect of the Constituents from Roots of Aglaia odorata (Meliaceae). Natural Products Research, 30(4), 1-5.
Ludwiczuk, A., Skalicka-Wozniak, K., \& Georgiev, M. I. (2017). Terpenoids. Pharmacognosy. 233-266.

Nugroho, B. W., Gussregen, B., Wray, V., Witte, L., Bringmann, G., \& Proksch, P. (1997). Insecticidal Rocaglamida Derivative from Aglaia elliptica and A. harmsiana. Phytochemistry, 45, 1579-1585.

Pan, L., Woodard, J. L., Lucas, D. M., Fuch, J. R., Kinghorn, A. D. (2014). Rocaglamida, silvestrol and structurally related bioactive compounds from Aglaia species. Natural Product Report, 31 (7), 924-939.

Pointinger, S., Promdang, S., Vajrodaya, S., Pannell, C.M., Hofer, O., Mereiter, K., Greger, H. (2008). Phytochemistry silvaglins and related 2,3-secodammarane derivatives - unusual types of triterpenes from Aglaia silvestris. Phytochemistry, 96 (15), 26962703.

Pan, L., Acuña, U. M., Li, J., Jena, N., Ninh, T. N., Pannell, C. M., Chai, H., Fuchs, J. R., Carcache De Blanco, E. J., Soejarto, D. D., Kinghorn, A.D. (2013). Bioactive flavaglines and other constituents isolated from Aglaia perviridis. Journal of Natural Products, 76, 394-404.

Ragasa, C.Y., Ganzon, J., Hofilena, J., Tamboong, B., \& Rideout, J.A. (2003). A New furanoid diterpene from Caesaipinia puicherrima. Chemical and Pharmaceutical Bulletin, 51(10), 1208-1210.

Roux, D., Martin, M., Adeline, M., Sevenet, T., Hadi, A.H.A., Pais, M. (1998). Foveolins A and $B$, dammarane triterenpes from Aglaia foveoflata. Phytochemistry, 49, 1745-1748.

Sianturi, J., Harneti, D., Darwati, Mayanti, T., Supratman, U., Awang, K. (2016). A New (-)-5',6-dimethoxyisolariciresinol-(3",4"-

dimethoxy)-3 $\alpha$-O- $\beta$-d-Glucopyranoside from The Bark of Aglaia eximia (Meliaceae). Natural Product Research, 30, 2204-2208.

Supratman, U., Naibaho, W., Salam, S., Maharani, R., Hidayat, A.T., Harneti, D., Nurlelasari, Shiono, Y. 2019. Cytotoxic triterpenoids from the bark of Chisocheton patens blume (Meliaceae). Phytochemistry Letters, 30, 8187.

Supriatno., Nurlelasari., Herlina, T., Harneti, D., Maharani, R., Hidayat, A.T., Mayanti, T., Supratman, U., Azmi, M.N., Shiono, Y. (2018). A new limonoid from stem bark of 
Chisocheton pentandrus (Meliaceae). from the leaves of Aglaia odorata. Natural Products Research, 25, 1-7. Phytochemistry, 76, 83-91

Yodsaove, O., Sonprasit, J., Karalai, C., Zhang, F., Wang, J.S., Gu, Y.C., Kong, L.Y. (2010). Ponglimanont, C., Tewtrakul, S., Triterpenoids from Aglaia abbreviata Chantrapromma, and their cytotoxic activities. Journal of S. (2012). Diterpenoids and triterpenoids with Natural Product, 73, 2042-2046. potential anti-inflammatory activity 